\title{
KONSEP "SATU TUNGKU TIGA BATU" SOSIO-KULTURAL FAKFAK SEBAGAI MODEL INTERAKSI DALAM KEHIDUPAN ANTARUMAT BERAGAMA
}

\author{
Daud Alfons Pandie \\ Dosen Program Pascasarjana STT Reformed Injili Internasional
}

\begin{abstract}
In the context of the plurality of religion in Indonesia, efforts to develop the study of "religious harmony" became very important. Unfortunately, the study about this topic is still very rare. Since the reform era of information, research focusing on aspects of religious harmony with the approach of the survey is still small in number, and its popularity is lower than the research information related to religious conflicts. This paper is one of the efforts to study the harmony between religious communities in the context of Fakfak on the Province of West Papua. Fakfak society objective conditions reflect the reality of oneness between the plurality of religion and a determination for unity person-to-person and person-to-place. There is not much difference in terms of ethnic and culture, but the reality of plurality can be seen clearly in terms of religion and local language with dialects into a typical form in the history of the Islands. To unite Fakfak society of Papua with such social and religious conditions like that, they make a consensus together to create a cultural system, referred to by the term "one-threestone stove". One-three-stone stove is seen as a cultural system that abstracted out from concrete events, used to understand things pertaining to life together as an individual and society. Unity in the cultural system of Fakfak society has a very strong adhesive power. Moreover, the condition of this community is characterized by its history in which three religions entered at the same time. This concept underlies the mindset and determines integration as a force of Papua's ethnic fraternity in spite of different religions. This cultural system is considered
\end{abstract}


as the one that gives direction and orientation to the citizens of the community to weave the solidarity between the same tribal culture, the harmony, the tolerance between ethnic groups, religions, and society. Cultural system called one-three-stone stove in Fakfak public life as a manifestation of the Fakfak cultural ideology is seen important and valuable so that it is used as a behavioural guideline in the inter-religious life of the people.

KEYWORDS: one-three-stone stove, interaction, religious people

ABSTRAK: Dalam konteks pluralitas agama di Indonesia, upaya mengembangkan studi tentang "kerukunan beragama" menjadi sangat penting. Sayangnya, studi tentang hal ini masih sangat langka. Sejak era reformasi informasi hasil penelitian yang berfokus pada aspek kerukunan antarumat beragama dengan pendekatan survei masih terasa kurang, dan popularitasnya lebih rendah dibanding dengan informasi penelitian yang terkait dengan konflik keagamaan. Tulisan ini adalah salah satu hasil upaya studi tentang kerukunan antarumat beragama dalam konteks masyarakat Fakfak di Provinsi Papua Barat. Kondisi objektif masyarakat Fakfak itu mencerminkan kesatuan realitas antara kemajemukan agama dengan tekad untuk bersatu antarorang per orang dan antarorang dan bumi tempat berpijak. Dari segi etnis dan budaya tidak banyak perbedaan, namun dari agama dan bahasa daerah dengan dialek ke dalam bentuk yang khas dari sejarah kepulauan itu, terlihat jelas realitas kemajemukan itu. Untuk menyatukan masyarakat Fakfak Papua dengan kondisi sosial dan keagamaan seperti itu, mereka membuat konsensus bersama untuk menciptakan suatu sistem budaya, yang disebut dengan istilah "satu tungku tiga batu". Satu tungku tiga batu dipandang sebagai sistem budaya yang diabstrakkan dari peristiwa konkret, yang digunakan untuk memahami hal-hal hidup kebersamaan secara individu dan masyarakat. Kesatuan dalam sistem budaya masyarakat Fakfak ini berdaya rekat yang kuat. Apalagi kondisi masyarakat diwarnai sejarah masuknya tiga agama pada masa yang 
sama. Konsep tersebut mendasari pola pikir dan menetapkan integrasi sebagai kekuatan persaudaraan etnis Papua, walaupun agama berbeda. Sistem budaya ini dianggap yang memberi arah dan orientasi kepada para warga masyarakat untuk menjalin solidaritas suku budaya yang sama, kerukunan, toleransi antar kelompok etnis, agama, dan sosial. Sistem budaya yang disebut satu tungku tiga batu dalam kehidupan masyarakat Fakfak tersebut sebagai wujud idiologi kebudayaan, dipandang penting dan bernilai sehingga dijadikan pedoman tingkah laku dalam kehidupan antarumat beragama.

KATA-KATA KUNCI: satu tungku, tiga batu, interaksi, umat beragama

Kenyataan yang telah menjadi salah satu aset kekayaan nasional Indonesia ialah adanya enam agama yang diakui negara, yakni : Hindu, Buddha, Katolik, Protestan, Islam, dan Kong Hu Chu, yang sama-sama diakui sah dan sama-sama mendapat hak hidup, berkiprah serta berkembang di seluruh wilayah negara Indonesia. Cukup menarik untuk diamati, keenam agama itu berinteraksi satu dengan yang lain. Interaksi itu pada satu pihak tampak berjalan dengan baik, namun pada pihak lain tidak sepi dari sisi-sisi yang sulit diterangkan. Pada satu pihak, adanya kegiatan yang melibatkan dan atau menyangkut keenam agama itu, tampak sangat positif, menyejukkan dan memberikan harapan. Tetapi pada pihak lain ditemukan adanya sikap agama yang terlalu formal, kurang substansial, terselubung, superior, inferior, dan mau menang sendiri. Kedua sisi itu tampak lekat pada kenyataan keagamaan ini.

Persoalannya adalah keenam agama yang diakui negara itu mesti berkiprah dalam satu masyarakat, bangsa dan negara Indonesia. Bagaimana kiprah seperti itu harus dipahami dan dihayati? Sisi-sisi yang sulit diterangkan ini memang bawaan agama yang dari sononya, yang harus diterima dan diberlakukan begitu saja. Ada juga yang mengatakan bahwa meskipun agama-agama itu lahir tanpa bersepakat lebih dahulu, namun karena perkembangan maka mereka saling bertemu, bahkan dianut oleh orang-orang yang serumah, se-RT, sekampung, sedesa dan 
seterusnya. Oleh karena itu agama-agama itu sekarang ini sudah menjadi milik dunia, tidak lagi mengenal batasan-batasan etnis, bahasa, geografis, politis, nasional, ekonomi, dan lain-lain¹."

Dengan perkataan lain, keenam agama yang semula sendirisendiri itu, sekarang dan selanjutnya harus mengakui kenyataan bahwa mereka tidak lagi sendiri-sendiri. Khususnya di Indonesia, mereka menjadi suatu pluralitas, dan mesti hidup dengan kenyataan itu. Dalam konteks itu, upaya mengembangkan studi tentang "kerukunan antarumat beragama" menjadi sangat penting. Sayangnya, studi tentang hal ini masih sangat langka. Sejak era Reformasi informasi hasil penelitian yang berfokus pada aspek kerukunan antarumat beragama dengan pendekatan survei masih terasa kurang, dan popularitasnya lebih rendah dibanding dengan informasi penelitian yang terkait dengan konflik keagamaan². Memang bisa dimengerti, seringkali studi tentang kerukunan keagamaan informasinya cenderung terasa datar, kurang tajam, tidak menggigit, dan tidak ada hal yang aneh sehingga kurang bermakna "informatif". Sedangkan hasil penelitian tentang konflik keagamaan informasinya sering sangat menarik dan menyentuh perasaan, karena mengejutkan, mengharukan, memprihatinkan dan membahayakan tertib sosial, apalagi kalau konflik keagaman itu membawa korban hilangnya harta benda, kekuasaan dan jiwa raga. Selain itu konflik keagamaan juga dipandang sebagai penyimpangan norma sosial dan budaya, yang kemunculannya seringkali tak terduga, tak terdeteksi, unorganized, dan perlu segera diatasi oleh negara. Mungkin, kerukunan keagamaan itu bagi bangsa Indonesia sudah menjadi hal yang sangat rutin dan biasa serta telah menjadi bagian dari kehidupan sehari-hari di berbagai pelosok Tanah Air. Hidup rukun,

1 Wismoady Wahono, "Pluralisme Agama di Indonesia" dalam Seminar Kajian Interdisipliner Agama-agama (Salatiga: Universitas Kristen Satya Wacana, 20 November 1992).

2 Bandingkan Syamsul Arifin, Studi Agama Perspektif Sosiologis dan Isu-isu Kontemporer (Malang: UMM Press, 2009), 63-98. 
damai dan saling menghargai antarteman dan tetangga, antarkampung dan kawasan, serta antarsuku bangsa yang berbeda paham keagamaan sudah membudaya dan bahkan sudah menjadi bagian dari kearifan lokal sejak berabad-abad yang lalu³, sehingga kerukunan keagamaan bagi kebanyakan orang bukan peristiwa atau masalah yang penting untuk dipublikasikan.

\section{Latar Belakang Konsep "Satu Tungku Tiga Batu" Sebagai Realitas Sosio - Kultural Masyarakat Fakfak}

Daerah Fakfak sejak dahulu kala telah dikenal sebagai daerah penghasil pala. Sampai saat ini kota Fakfak dijuluki "kota pala", karena sejak dulu sampai sekarang hasil bumi terbesar Fakfak adalah pala. Pada awalnya, Fakfak dikenal sebagai Jazirah Onim, yang biasanya juga disebut Kapaur yang terdiri dari berbagai kerajaan kecil. "Daerah ini dimiliki oleh raja-raja Ati-ati, Fatagar, Wartuar, Sekar, Pikpik, Patipi, Rumbati, dan Arguni" ${ }^{4}$. Pada umumnya daerah ini dikuasai oleh para pendatang, maksudnya adalah bahwa ada raja-raja yang berasal dari luar Papua, jadi bukan dari penduduk asli. Daerah Kapaur disukai oleh para pedagang karena adanya hutan-hutan pala. Bertahun-tahun sebelum adanya pusat pemerintahan, para pedagang lebih dahulu telah datang ke daerah ini, seperti para pedagang Seram, Gorom, Bugis, Makassar, Arab, dan Cina. Terutama orang-orang Seram mempunyai pengaruh yang besar di daerah ini karena kebanyakan dari mereka kawin dengan wanita daerah ini. Sebaiknya banyak wanita Seram dikawinkan dengan pemuda-pemuda daerah Kapaur. Hingga saat ini, banyak orang

\footnotetext{
3 Haidlor Ali Ahmad (ed), Survei Kerukunan Umat Beragama di Indonesia" (Jakarta: Puslitbang Kehidupan Keagamaan Badan Litbang dan DiklatKementerian Agama RI, 2013), viii. Hasil penelitian Badan Litbang Agama tahun 1989/1990, memberikan contoh tradisi hidup rukun, damai, tidak saling mengganggu antar penganut Buddha dan Hindu sejak masa kerajaan Sriwijaya tahun $629 \mathrm{M}$ telah berkembang (Bahrul Hayat, Mengelola Kemajemukan Umat Beragama (Jakarta: Saadah Cipta Mandiri, 2012)).

4 F. Slump, Sejarah Penginjilan di Daerah Kapaur 1918-1930 (Fakfak: STT GPI Papua, 1990), 1 .
} 
berdatangan ke Fakfak dan berdiam di wilayah-wilayah yang ada. Mereka antara lain berasal dari Maluku, kepulauan Kei, Tepa, Dobo, Tanimbar, Flores (NTT), Toraja, Kaimana, Mimika, Serui, Biak dan Sorong. Ini menjadikan masyarakat Fakfak saat ini sangat heterogen.

Dalam kaitan dengan konsep "satu tungku tiga batu" di dalam tulisan ini, pengamatan dan pemahaman penulis ini dikhususkan pada tiga agama yaitu: Protestan, Katolik, dan Islam, yang para pemeluknya dapat hidup dan menjalin hubungan dengan harmonis di wilayah Fakfak Papua sejak tahun 1912, yaitu sejak Injil pertama kali masuk di wilayah ini. Masyarakat tersebut bersifat heterogen, yang terdiri dari berbagai etnis Papua seperti: Ayamaru, Kaimana, Agimuga, Kokonau, Serui, Biak, dan Inanwatan, yang telah lama mendiami wilayah itu, yaitu sejak sekitar Tahun 1961. Masing-masing etnis mempunyai bahasa daerah dan adat-istiadatnya. Kenyataan seperti ini dalam masyarakat tersebut sebenarnya merupakan warisan sejarah dengan masuknya suku bangsa lain dari sekitar Papua sebagaimana dikemukakan oleh P. Muskita:

Para penduduk yang mendiami wilayah Jazirah Onin sampai Kowiyai (Namatota) tercatat telah mempunyai hubungan dagang dengan kerajaan Sriwijaya, Majapahit, Kesultanan Tidore, serta Maluku jauh sebelum kedatangan bangsa-bangsa Barat yang pernah menduduki wilayah Papua. Dalam sejumlah naskah sejarah, sebelum tahun 1898 nama Fakfak belum disebut. Nama yang sering disebut adalah Onim, Kapaur, dan Kokas. Penduduk jazirah onin mempunyai berbagai bahasa seperti: Bahasa Iha (daerah pantai disebut Kapaur), Onim, Sekar, Arguni, Eroanas, Bendoanas, Mor, Tanah Mera, Baham atau Patimuni, Karas Laut, Karas Darat, Irarutu, Asienara, Iria dan Kowai. ${ }^{5}$

Masyarakat Papua dewasa ini, yang menganut agama Katolik, Protestan, dan Islam, pada mulanya menganut agama suku. Cara hidup mereka untuk merebut dan mempertahankan tempat tinggalnya adalah dengan berperang. Perang antarsuku ini sering terjadi karena mereka tidak mau menerima orang lain di luar dari komunitas mereka. Seiring

5 P. Muskita, Fakfak dari Zaman Pra Histori Sampai dengan Tahun 1969 (Fakfak: Kantor Wilayah Departemen Agama Fakfak, 1983), 9. 
dengan perkembangan zaman dan keterbukaan masyarakat untuk kedatangan para penginjil Indische Kerk, badan misi Ora et Labora dan Biji Sesawi, rupanya memberikan penyuluhan-penyuluhan bukan saja menyangkut aspek religius, tetapi juga pendidikan dan kesehatan, yang lambat laun diterima dan juga diterapkan masyarakat setempat. Selanjutnya, dari penyebaran agama yang masuk itu terjadi penetrasi ajaran dari tiga agama tersebut yakni: Protestan, Katolik, dan Islam kepada masyarakat Fakfak. Karena itu penyebaran ketiga agama itu diasumsikan masuk dan diterima ke wilayah Fakfak Papua pada masa yang sama. ${ }^{6}$ Maka selanjutnya masyarakat Fakfak menggunakan kebebasan beragama untuk memilih dan menganut agama-agama tersebut.

Sementara itu, kehidupan beragama masyarakat Fakfak tetap eksis dan berjalan dengan baik. Kehidupan religius masing-masing warga diekspresikan melalui pelbagai bentuk agama yang diyakininya, baik itu yang merupakan warisan nenek moyang maupun yang datang dari luar. Begitu pula hubungan sosial antarumat beragama terjalin harmonis. Kiprah yang bersifat positif itu menunjukkan bahwa agama-agama bukan hanya melekat pada masa yang lampau, tetapi juga tampak berusaha untuk menggapai masa yang akan datang.

Hal di atas tampak bukan hanya dari isi kegiatan keagamaan, seperti: partisipasi untuk membangun rumah ibadah dari kelompok agama tertentu, dan/atau turut hadir pada pada hari raya kelompok lain, dan sebagainya, tetapi juga dari semangat masing-masing agama yang mulai membuka diri satu terhadap yang lain. Umpamanya saja, agamaagama tersebut mulai tahu bahwa di dalam diri mereka masing-masing tersimpan benih-benih ajaran-ajaran yang sangat positif dan kreatif dalam kehidupan secara bersama.

6 Rikjan Iba, “Selayang Pandang Jemaat Rangkendak”, makalah yang disampaikan dalam Seminar Sejarah Masuknya Injil di Fakfak (Fakfak: GPI Papua 16 Januari 2002). 
Kondisi objektif masyarakat Fakfak itu mencerminkan kesatuan realitas antara kemajemukan agama dengan tekad untuk bersatu antarorang per orang dan antarorang dan bumi tempat berpijak. Dari segi etnis dan budaya tidak banyak perbedaan, namun dari agama dan bahasa daerah dengan dialek ke dalam bentuk yang khas dari sejarah kepulauan itu. Untuk menyatukan masyarakat Fakfak Papua dengan kondisi sosial dan keagamaan seperti itu, mereka membuat konsensus bersama untuk menciptakan suatu sistem budaya, yang disebut dengan istilah "satu tungku tiga batu". Satu tungku tiga batu dipandang sebagai sistem budaya yang diabstrakkan dari peristiwa konkret, yang digunakan untuk memahami hal-hal hidup kebersamaan secara individu dan masyarakat. Kesatuan dalam sistem budaya masyarakat Fakfak ini berdaya rekat yang kuat. Apalagi kondisi masyarakat diwarnai sejarah masuknya ketiga agama tersebut pada masa yang sama. Konsep tersebut mendasari pola pikir dan menetapkan soal integrasi sebagai kekuatan persaudaraan etnis Papua, walaupun agama berbeda.

Sistem budaya ini dianggap memberi arah dan orientasi kepada para warga masyarakat untuk menjalin solidaritas suku budaya yang sama, kerukunan, toleransi antarkelompok etnis, agama, dan sosial. Sistem budaya yang disebut satu tungku tiga batu dalam kehidupan masyarakat Fakfak tersebut sebagai wujud ideologi kebudayaan, dipandang penting dan bernilai sehingga dijadikan pedoman tingkah laku dalam kehidupan antarumat beragama.

Kekhususan sistem budaya masyarakat Fakfak, yang penerapannya tampak pada sifat dan sikap toleransi antarumat beragama pada kalangan Protestan, Katolik, dan Islam menjadi alasan penulis untuk membahasnya dalam tulisan ini. Selanjutnya sebagai refleksi atas semangat toleransi antarumat beragama itu penulis kemukakan pendekatan misi yang kontekstual khususnya pada kalangan Protestan. Dengan demikian, golongan Protestan dan masyarakat Fakfak ada bukan untuk dirinya sendiri atau untuk saling ada, melainkan ada untuk keberadaan dan kehidupan bersama. 


\section{Pemahaman Sosio-Kultural Fakfak mengenai Konsep Satu Tungku Tiga Batu}

Masyarakat dapat dipahami sebagai suatu bentuk penataan hidup yang sedikit banyak bersifat mandiri. Ia adalah pola hubungan hidup yang tertib (antara pribadi-pribadi yang hidup bersama-sama), yang mempunyai realitas dan obyektifitas tertentu yang bersifat mandiri antara individu-individu dalam masyarakat tersebut. ${ }^{7}$ Berdasar pada pengertian ini, pertama-tama harus dipahami latar belakang pemahaman masyarakat Fakfak sendiri tentang konsep satu tungku tiga batu.

1. Pemahaman Filosofis

Konsep "satu tungku tiga batu" merupakan suatu nilai budaya yang pertama-tama bertalian erat dengan sistem kekerabatan suku.

a. Satu Tungku

Secara filosofis, anologi tungku diartikan sebagai "tanah, daerah atau negeri". Menurut Marten Hindom:

Tungku dalam bahasa daerahnya disebut "hirriet". Harafiahnya hirriet bisa berarti kebun, tanah atau negeri. Jadi kata ini menunjuk pada wadah di mana agama Kristen Protestan, Katolik dan Islam hidup dan bertumbuh. Kata ini juga menunjuk pada daerah Fakfak sebagai tempat di mana ketiga agama hidup dan berkembang. ${ }^{8}$

Tak bisa disangkal, tanah merupakan pusat dari segala unsur kehidupan dalam alam ini. Begitu pentingnya tanah, maka adalah sangat sulit bagaimana manusia itu bisa hidup tanpa memiliki tanah. Menurut Karel Phil. Erari:

Karena tanah, maka suatu bangsa akan terus berjuang dengan segala akibatnya, kendati itu harus dibayar dengan darah. Dalam sejarah bangsa Israel, kita belajar bagaimana bangsa Israel tampil sebagai suatu bangsa

\footnotetext{
7 Theodore M. Steeman, "Religious Pluralism and National Integration", Ph.D. Dissertation (Harvard University, 1973), 12.

8 Marten Hindom adalah salah satu sesepuh dan tokoh masyarakat Papua. Pernah menjabat sebagai Ketua Sinode GPI Papua menjadikan beliau selalu intens berinteraksi dengan masyarakat dari berbagai etnis di Wilayah Fakfak.
} 
yang kuat dan berani, karena bagi mereka tanah adalah sebuah janji. ${ }^{9}$

Dalam pemahaman masyarakat Fakfak, tanah adalah sumber hidup manusia dan segala makhluk hidup. Oleh sebab itu, tanah harus dihormati dan dilindungi, agar hidup manusia dapat terjamin. Tanah adalah tempat berpijak bagi manusia, dan tanah menentukan siapa diri kita. Tanah punya dua fungsi utama, yaitu: pertama, tanah adalah tempat mendirikan rumah. Kedua, tanah memberi kehidupan dan menjamin masa depan. Masyarakat suku di Fakfak tidak pernah merasa terpisah dari alam sekitarnya. Mereka adalah bagian tidak terpisahkan dari alam ini. Karena itu, bila manusia merusak alam, dengan sendirinya ia merusak dirinya sendiri.

b. Tiga Batu

Secara filosofis, anologi tiga batu pertama-tama melambangkan tiga sendi kehidupan bermasyarakat, yaitu adat, pemerintah dan agama dan yang kedua melambangkan tiga agama sebagai tiang penopang dalam kehidupan masyarakat Fakfak, yaitu agama Kristen Protestan, Katolik, dan Islam. Karena itu dalam sebuah keluarga besar yang mengusung fam (marga) tertentu, sering didapati ada anggota keluarga yang menganut agama Kristen Protestan, ada yang menganut agama Katolik, dan ada yang menganut agam Islam. Contohnya dalam keluarga yang berfam Hindom, ada yang menganut agama Kristen Protestan, ada yang Katolik dan ada yang menganut agama Islam meskipun mereka hidup serumah. Menurut Marthen Hindom: “Tiga anggota keluarga dengan agama yang berbeda ini bagaikan tiga batu dalam satu tungku. Karena itu bagaimana saya bisa memusuhi orang Islam sedangkan ada orang fam Hindom yang ternyata Muslim?

Penjelasan Marten Hindom di atas dapat diakui kebenarannya jika melihat salah satu kebiasaan di dalam rumah keluarga Kristen yang menyediakan alat-alat makan, minum dan alat masak yang tidak pernah

9 Karel Phil Erari, Tanah Kita, Hidup Kita (Jakarta: Pustaka Sinar Harapan, 1999), 20-21. 
digunakan sehari-hari. Alat-alat itu baru digunakan bila ada tamu Muslim atau pesta yang dihadiri oleh kaum Muslim. Tujuannya agar orang Islam tidak ragu makan dan minum di rumah tersebut. Tradisi menyuguhkan daging ayam atau kambing untuk tamu Muslim juga sangat kental di sini. Bila seorang Muslim menjadi tamu pada keluarga non-Muslim, dipastikan akan ditawarkan untuk menyembelih ayam atau kambing, yang kemudian diadakan acara makan bersama.

Lebih jauh lagi, misalnya dalam suatu perkampungan di daerah Fakfak sering terdapat tiga rumah ibadah, baik dari agama Kristen Protestan, Katolik maupun agama Islam. Menurut Lukas Mury:

Tiga batu mengartikan suatu nilai kerukunan dan kekeluargaan. Jika salah satu batu tidak ada, maka tidak mungkin kegiatan memasak terlaksana. Dengan demikian akan berpengaruh pada keharmonisan dan keselarasan hidup". Karena itu ketika ada pembangunan rumah Mesjid, kami selalu menjadi panitia pembangunan Mesjid tersebut. Demikian pula ketika kami akan merenovasi gereja, saudara-saudara kami yang Muslim selalu melibatkan diri jadi panitia pembangunan. ${ }^{10}$

Di dalam acara-acara keagamaan juga tampak terjalin suasana keharmonisan yang tinggi. Misalnya pada acara Malam Takbiran, seringkali mereka yang beragama Kristen terlibat aktif di dalamnya. Demikian pula dalam perayaan Natal, mereka yang beragama Islam turut terlibat secara aktif. Di samping itu, ketika pejabat pemerintah berkunjung ke suatu perkampungan, penyambutannya dilakukan oleh adat masing-masing agama. Yang beragama Kristen menyambut dengan suling dan nyanyian-nyanyiannya, sedangkan yang Muslim menyambut dengan musik tifa dan rebana disertai dengan nyanyian-nyanyiannya.

Dalam kaitannya dengan keberadaan suku Mba' ham Mata, konsep satu tungku tiga batu juga sangat terasa filosofis. Tiga batu menunjuk pada tiga sub suku dari suku Mba' ham Mata di masyarakat

\footnotetext{
10 Lukas Mury adalah tokoh masyarakat Fakfak yang pernah bekerja pada instansi pemerintah daerah Fakfak. Sampai pada masa pensiunnya, beliau concern terhadap upayaupaya menjaga kerukunan antarmasyarakat di daerah Fakfak.
} 
Fakfak, yaitu: sub suku Baham mewakili agama Kristen Protestan, Mata yang merupakan gabungan antara tiga agama dan Iramaika yang mewakili agama Islam.

Dalam perkembangan selanjutnya, konsep satu tungku tiga batu juga dikaitkan dengan keberadaan hidup masyarakat Fakfak secara menyeluruh. Anologi tiga batu juga kemudian dikaitkan dengan keberadaan pemerintah, agama, dan adat. Ketiga unsur ini merupakan tiga pilar yang menopang jalannya kehidupan masyarakat Fakfak. Konsep satu tungku tiga batu juga merupakan kesepakatan bersama masyarakat Fakfak sebagai prasyarat utama interaksi antara pemerintah, agama dan adat. Ketiga unsur ini disatukan pemahamannya melalui konsep ini. Dengan demikian diharapkan tidak ada pertentangan antara kebijakan pemerintah dengan ajaran ketiga agama yang ada, demikian juga antara pemerintah dan adat.

Dari pemahaman-pemahaman yang diungkapkan di atas, dapat dilihat bahwa keberadaan "tungku" ditentukan oleh "tiga batu". Dengan kata lain, tanpa "tiga batu" sebuah tungku tidak mungkin ada. Dalam kaitan dengan hal ini, Keberadaan dan keberlangsungan kehidupan masyarakat ditentukan oleh ketiga unsur utama, yaitu agama, pemerintah dan adat. Ketiganya berada dalam posisi yang sejajar. Jika salah satu unsur disingkirkan maka tatanan dan interaksi sosial masyarakat Fakfak akan terganggu.

\section{Fungsi}

Dalam perkembangan masyarakat Fakfak saat ini yang semakin terbuka terhadap dunia luar, kemajemukan merupakan realitas utama yang paling tampak. Dalam bagian terdahulu telah dikemukakan bahwa "saat ini masyarakat Fakfak terdiri dari beragam etnis, baik yang asli “Papua maupun pendatang dari luar Papua. Etnis asli Papua yang mendiami daerah Fakfak adalah etnis Ayamaru, Kaimana, Agimuga, Kokonau, Serui, Biak, Inanwatan, yang telah lama mendiami wilayah ini, di samping suku asli Fakfak, yaitu Mba' Ham Mata. Sedangkan yang dari 
luar etnis Papua berasal dari etnis Ambon, Timor, Flores, Jawa, Buton (Sulawesi Selatan). Dari gambaran ini terlihat jelas bahwa masyarakat Fakfak bersifat heterogen.

Dari sisi agama pun, heterogen sifatnya. Selain ketiga agama, yaitu Protestan, Katolik dan Islam, telah ada penganut agama lain seperti Hindu dan Buddha meskipun persentase penganutnya masih sangat sedikit. Dengan realitas masyarakat yang multietnis dan agama seperti yang dikemukakan di atas, ternyata konsep satu tungku tiga batu masih relevan. Ini terbukti dari keberadaan masyarakat yang sangat toleran satu terhadap yang lain, sehingga kerukunan hidup beragama dan bermasyarakat tetap terjaga. Konflik antaretnis dan antaragama dapat dikatakan tidak pernah terjadi.

Di samping berfungsi menjaga kerukunan, konsep tungku tiga batu kemudian berfungsi sebagai ídentitas masyarakat Fakfak. Identitas yang dimaksud di sini merupakan nilai-nilai yang telah membentuk diri manusia secara individu maupun kelompok yang mengejawantah dalam sikap dan perilaku di manapun ia berada. Sikap yang toleran, mendahulukan kepentingan umum daripada kepentingan pribadi, jujur, tidak suka mencampuri urusan orang lain dan mengasihi merupakan beberapa nilai yang menjadi identitas masyarakat di samping nilai-nilai kebajikan yang lain.

\section{Refleksi Budaya Fakfak terhadap Konsep Satu Tungku Tiga Batu}

Salah satu cara untuk memahami kebudayaan dan konsep hidup suatu daerah adalah dengan membandingkannya dengan kebudayaan dan konsep hidup daerah lain. Meskipun demikian, perlu disadari bahwa tidak ada satu budaya pun yang dapat dijadikan sebagai tolok ukur untuk menilai budaya daerah lain. Setiap budaya dan konsep hidup suatu daerah memiliki keunikan tersendiri. Karena itulah untuk memahami konsep "satu tungku tiga batu' dalam kehidupan masyarakat diperlukan suatu refleksi terhadap kebudayaan itu sendiri. 
Bertolak dari maksud di atas, maka dalam hal ini refleksi budaya dapat dipahami sebagai suatu upaya untuk masuk ke dalam dunia konseptual budaya dan masyarakat Fakfak. Refleksi budaya berusaha memahami nilai-nilai, konsep dan gagasan-gagasan yang melaluinya masyarakat Fakfak hidup, serta memahami baik pengalamanpengalamannya sendiri maupun tempat di mana mereka hidup.

Masyarakat dapat dipahami sebagai suatu bentuk penataan hidup yang sedikit-banyak bersifat mandiri. "Ia adalah pola hubungan hidup yang tertib (antara pribadi-pribadi yang hidup bersama-sama), yang mempunyai realitas dan obyektivitas tertentu yang bersifat mandiri antara individu-individu dalam masyarakat tersebut". ${ }^{11}$

Berdasarkan uraian tentang pemahaman dan fungsi konsep satu tungku tiga batu yang dikemukakan di atas, maka dapat dikemukakan beberapa nilai yang terkandung di dalamnya.

1. Kerukunan atau Kejujuran?

Masyarakat tidak ada tanpa orang-orang yang membentuknya. Tapi sebaliknya juga orang-orang itu tidak dapat hidup tanpa masyarakat. Menurut Eka Darmaputera:

Manusia adalah makhluk sosial. Untuk menjadi dirinya sendiri, ia membutuhkan orang lain. Dimensi sosial ini tidak sekadar merupakan lampiran tambahan kepada hakikat manusia, sekadar untuk tujuan-tujuan praktis. Ia merupakan sesuatu yang inheren pada hakekat manusia sendiri. Individu-individu itu mempunyai kepentingan terhadap masyarakat dan keberesannya, dan oleh karena itu secara pribadi mengambil bagian dalam proses sosial. ${ }^{12}$

Pertanyaan yang dapat dikemukakan adalah: apakah yang dapat membuat masyarakat Fakfak yang heterogen, baik secara etnis maupun agama, secara sukarela menjadikan kerukunan sebagai pola hidup? Jawabannya dapat diungkapkan secara negatif maupun positif.

11 Theodore M. Steeman, "Religious Pluralism and National Integration", Ph.D. Dissertation (Harvard University, 1973), 12.

12 Eka Darmaputera, Pancasila: Identitas dan Modernitas (Jakarta: BPK Gunung Mulia, 1997), 9. 
Secara negatif, artinya kerelaan itu didorong oleh karena masyarakat Fakfak membutuhkan masyarakat berjalan dengan baik, dan masyarakat tak dapat berjalan dengan baik tanpa "pengorbanan". Jika masing-masing etnis dan agama menampilkan "ego" dan memaksakan kehendaknya, maka kerukunan akan hilang. Yang ada hanyalah konflik yang akan terjadi terus-menerus. Secara positif, artinya, oleh karena "pengorbanan" itu tidak saja dianggap perlu, tetapi juga "benar dan baik". Apa yang secara formal membentuk sebuah masyarakat adalah penerimaan umum semua anggota masyarakat terhadap sebuah pola tingkah laku yang normatif. Pola tingkah laku yang normatif inilah yang harus dipandang sebagai unsur paling teras dari fenomena masyarakat sebagai sebuah struktur yang terintegrasi. ${ }^{13}$

Jadi, yang membuat masyarakat Fakfak bersedia hidup dengan konsep satu tungku tiga batu sekalipun dengan mengorbankan kebebasannya adalah oleh karena konsep hidup ini mereka yakini benar, baik dan perlu. Dengan demikian, keberadaan masyarakat Fakfak dapat berfungsi apabila anggota-anggota masyarakat yang multietnis bersedia mengintegrasikan diri di bawah konsep hidup satu tungku tiga batu tersebut. Kehidupan bersama dapat terwujud karena masyarakat mematuhi dan bersedia hidup di dalam nilai-nilai yang terkandung di dalamnya.

Kerukunan hidup di sisi lain mempunyai makna yang negatif. Orang Fakfak pada umumnya merasa bahwa masyarakat mereka merupakan sebuah masyarakat "rukun" walaupun mungkin ada perbedaan pemahaman di dalamnya. Rukun sebagai salah satu unsur dalam pandangan hidup satu tungku tiga batu dinilai sebagai sesuatu yang baik, yang perlu dihadirkan dalam relasi sosial seorang individu dengan individu-individu. Di sini rukun dinilai lebih penting, lebih baik daripada "kejujuran". Menurut Marten Hindom, “Orang Fakfak adalah orang yang "iya" walaupun hatinya tidak suka. Tetap tersenyum,

13 Steeman, Religious Pluralism, 19. 
walaupun hati marah, karena senyuman akan menghasilkan ketenteraman pada hati orang lain, dan dari sini akan lahir kerukunan. Kemarahan dan kesedihan yang ditampilkan secara nyata akan mengganggu orang lain. Inilah yang membuat masyarakat kehilangan hak-hak atas tanah dan hutan, karena tidak terbuka mengemukakan maksudnya terhadap eksplorasi oleh perusahaan-perusahaan dari luar."

Dari sisi ini kejujuran menjadi kurang nilainya daripada kerukunan. Sikap pura-pura (apatis) dianggap lebih baik dari pada berterus-terang. Karena dengan pura-pura, orang lain tidak akan tersinggung atau tersakiti perasaannya. Sebaliknya kejujuran seringkali dipandang tidak tepat, karena kejujuran bisa membuat orang lain tersinggung, dan ini dapat merusak hubungan sosial, dapat merusak kerukunan

\section{Kerukunan agama atau Sinkretisme?}

Secara sosiologis, agama adalah "suatu jenis sistem sosial yang dibuat oleh penganut-penganutnya yang berporos pada kekuatankekuatan non-empiris yang dipercayai dan digunakan untuk mencapai keselamatan bagi diri mereka dan masyarakat luas umumnya". ${ }^{14}$ Agama kemudian mengemban fungsi memupuk persaudaraan.

Dalam realitas dunia umumnya, agama-agama lebih cenderung menjadi sumber konflik dan perpecahan daripada mengemban fungsinya di atas. Menurut Hendropuspito, ada tiga faktor konflik sosial yang bersumber dari agama. "Pertama, perbedaan doktrin dan sikap. Kedua, perbedaan suku dan ras umat beragama. Ketiga, masalah mayoritas dan minoritas pemeluk agama. ${ }^{15}$

Dalam realitas kehidupan masyarakat Fakfak, perbedaan doktrin dan sikap, suku dan ras, serta masalah mayoritas bukan menjadi penghalang untuk menciptakan kehidupan persaudaraan yang rukun.

14 D. Hendropuspito, Sosiologi Agama (Jakarta: BPK Gunung Mulia \& Yogyakarta: Kanisius, 1999), 151.

15 Ibid., 160. 
Masing-masing agama membuka diri dan bergaul dengan saling terbuka. Jika ditinjau dari luar kehidupan masyarakat Fakfak, ada pemahaman yang salah yang menyatakan bahwa kehidupan beragama di Fakfak bersifat sinkretis. Untuk bisa menentukan apakah pola hidup beragama di Fakfak adalah sinkretis atau tidak, berikut ini dikemukakan pemahaman tentang sinkritisme. Neils Mulder mengartikan "Sinkretisme sebagai upaya untuk menenggelamkan berbagai sekte atau aliran filsafat". ${ }^{16}$ Dengan kata lain, upaya menghasilkan kesatuan itu merupakan tujuan tertinggi; dan demi hal itu dianggap pantas untuk mengorbankan prinsip dan dogma.

Dalam antropologi dan teologi modern, istilah sinkretisme itu paling sering dipakai untuk menggambarkan upaya memadukan berbagai unsur yang terdapat di dalam bermacam pembicaraan sehubungan dengan masalah keagamaan, tanpa memecahkan berbagai perbedaan dasar dari prinsip-prinsip yang ada di dalamnya. Dengan demikian, istilah sinkretisme juga menunjuk pada percampuran dan perpaduan yang merupakan akibat umum dari persinggungan atau kontak kebudayaan.

Dalam konteks kehidupan beragama di Fakfak, jika merujuk pada uraian di atas, maka sebenarnya tidak ada unsur sinkretisme di dalamnya. Dalam soal doktrin dan pola hidup beragama, tidak ada pencampuran di dalamnya. Yang ada justru hanyalah perpaduan sikap yang hampir serupa dalam masing-masing ajaran agama yang ada di Fakfak. Ini terjadi karena agama tidak diperhadapkan secara bertentangan dengan adat dan pemerintah, tetapi sejajar seperti yang telah diuraikan dalam konsep satu tungku tiga batu pada bagian atas.

\footnotetext{
16 Neils Mulder, Agama, Hidup Sehari-hari dan Perubahan Budaya (Jakarta: Gramedia, 1998),
} 5. 


\section{Penilaian: Keunggulan dan Keterbatasan Konsep satu tungku tiga batu}

\section{Keunggulan}

Pada bagian atas telah dikemukakan pemahaman dan fungsi konsep satu tungku tiga batu serta refleksi budaya terhadapnya. Oleh karena itu agar tidak terjadi pengulangan, pada bagian ini secara ringkas dapat dikatakan bahwa dalam realitas kehidupan masyarakat Fakfak yang multietnis dan multiagama, konsep satu tungku tiga batu masih menjadi pilihan terbaik.

Konsep satu tungku tiga batu memang bukan merupakan suatu hukum tertulis yang menciptakan nilai-nilai baru, tetapi konsep ini telah berakar dalam budaya masyarakat Fakfak. Dari sisi ini dapat dikatakan bahwa konsep ini merupakan salah satu warisan budaya masyarakat Fakfak.

\section{Keterbatasan}

Masyarakat terdiri dari individu-individu yang tentunya tidak lepas dari pengaruh-pengaruh di luar lingkungan ketika ia berusaha mengembangkan jati dirinya. Demikian juga halnya dengan masyarakat Fakfak. Ada ungkapan bahwa "tak ada gading yang tak retak". Tidak ada apa pun di dunia ini yang sempurna, kecuali Tuhan sendiri.

Konsep satu tungku tiga batu menurut penulis, mempunyai keterbatasan. Hal menarik adalah seperti yang dikemukakan dalam bagian refleksi budaya terhadap konsep satu tungku tiga batu. Nilai kerukunan yang menjadi penekanan dalam konsep ini ditempatkan lebih tinggi dari kejujuran. Dengan demikian hidup akan menjadi apatis. Dinamika hidup menuju perkembangan akan berjalan lambat. Meskipun demikian, sampai sejauh ini, konsep satu tungku tiga batu masih relevan dan mampu mengakomodasi berbagai perbedaan yang timbul dalam keberadaan kehidupan beragama dan bermasyarakat. 
Konsep "Satu Tungku Tiga Batu" sebagai Model Pendekatan dalam Interaksi Umat Beragama di Indonesia

Dalam sejarah, dialog antarnarasi pengalaman iman merupakan kondisi yang menjamin peradaban manusia. Di Indonesia, pertemuan antara budaya Hindu, Buddha, Islam dan budaya Eropa telah melahirkan begitu banyak kemajuan dalam peradaban modern dan telah menjadikan Indonesia menjadi hotbed bagi cara pandang dan cara berpikir. Salah satu hasil dialektika antarnarasi pengalaman kultural ini adalah dirumuskannnya "Bhineka Tunggal Ika" sebagai prinsip atau pilar hidup berbangsa dan bernegara. Sayangnya, situasi di Indonesia akhir-akhir ini mencatat beberapa kenyataan suram dalam konteks hidup berbangsa dan bernegara yang dinilai "rawan secara nasionalis dan menggelisahkan secara teologis"17.

Pendekatan dalam interaksi umat beragama harus bertolak daripada dua sisi. Pertama, pemahaman bahwa Indonesia adalah "tanah dan rumah bagi semua". Karena itu tujuan dari pendekatan yang dimaksud adalah bagaimana menjadikan Indonesia sebagai bagian hidup seluruh masyarakat Indonesia. Sisi kedua adalah dari keberagaman agama dan budaya Indonesia sendiri yang memiliki nilainilai hidup yang universal. Belajar dari interaksi yang terjadi antarumat beragama di Indonesia, maka perlu dikembangkan suatu pendekatan interaksi yang bersifat inkslusif, dan komprehensif yang mencakup semua orang. Pendekatan ini harus menjembatani jurang antara semua golongan, menghancurkan tembok-tembok kebencian dan menerobos batas-batas antara individu, kelompok, agama dan kebudayaan.

Agama dan kebudayaan diperuntukkan bagi manusia dengan segala kandungan kemanusiaan. Dengan demikian, dialog antarumat beragama dalam konteks keberagaman haruslah menggugat nurani

\footnotetext{
17 Nico J. Wolly, “Berteologi dan Menggereja Secara Kontekstual dalam Situasi Politik di Indonesia" dalam Greg Neonbasu (ed), MULTIKULTURISME PEMBANGUNAN, Refleksi Struktural atas Karya Manusia (Maumere: Ledalero, 2012), 250.
} 
setiap umat beragama untuk memberi prioritas kepada manusia dan kemanusiaan itu sendiri, karena "Allah tidak perlu dibela"18. Dialog yang benar adalah dialog sebagai saudara, sebagai sebuah keluarga manusia.

Berdasarkan uraian tentang pendekatan interaksi di atas, maka dalam konteks kehidupan berbangsa dan bernegara, pendekatan yang dilakukan haruslah bersifat komprehensif. Artinya, pendekatan interaksi itu dilakukan secara utuh dan menyeluruh bagi kebutuhan manusia. Dengan demikian pendekatan ini juga harus bersifat dialogis atau komunikatif. Dalam konteks umat beragama di Indonesia, salah satu upaya komunikasi adalah dengan melakukan pendekatan dengan mencari "titik temu". Titik temu ini dapat berupa nilai-nilai universal dalam agama dan kebudayaan Indonesia. Nilai-nilai yang dimaksud yaitu kerukunan dan toleransi.

Dari sudut pandangan agama, perumusan kata-kata Pancasila sendiri menggambarkan suatu kompromi ${ }^{19}$ sebagai upaya mencari titik temu yang dimaksud di atas. Golongan-golongan Islam tertentu menghendaki agar perumusan ideologi secara khusus menyebutkan Islam; tetapi Soekarno, yang selalu menekankan pentingya persatuan nasional dan berusaha memuaskan semua golongan agama, memilih istilah yang lebih luas, yakni Ketuhanan Yang Maha Esa ${ }^{20}$.

\section{Penutup}

Konsep budaya yang disebut satu tungku tiga batu dalam kehidupan masyarakat Fakfak tersebut sebagai wujud ideologi kebudayaan, dipandang penting dan bernilai sehingga dapat dijadikan pedoman tingkah laku dalam kehidupan antarumat beragama. Kekhususan konsep budaya masyarakat Fakfak, penerapannya tampak pada sifat dan sikap toleransi antarumat beragama pada kalangan

\footnotetext{
18 Abdurrahman Wahid, Tuhan Tidak Perlu Dibela (Yogyakarta: LKS 2010), xxxv.

19 Roeslan Abdulgani, Pancasila, Penggerak Utama Revolusi Indonesia (Jakarta: Prapanca, 1965), 106.

20 Donald Wilhem, Indonesia Bangkit (Jakarta: Universitas Indonesia Press, 1981), 153.
} 
Protestan, Katolik, dan Islam. Dengan demikian, golongan Protestan dan masyarakat Fakfak Papua ada bukan untuk dirinya sendiri atau untuk saling ada, melainkan ada untuk keberadaan dan kehidupan bersama.

Dalam konteks budaya Fakfak, salah satu upaya interaksi dan komunikasi adalah dengan melakukan pendekatan dengan mencari "titik temu". Titik temu ini dapat berupa nilai-nilai universal dalam kebudayaan Fakfak. Nilai-nilai yang dimaksud telah dikemukakan pada bagian terdahulu, yaitu kerukunan dan toleransi. Dalam kaitan dengan hal ini, maka pendekatan interaksi antarumat beragama mendapat "titik masuk" dari sistem kekeluargaan atau kekerabatan yang terjalin dengan rukun. Dalam konteks ini, maka pendekatan interaksi yang dilakukan pertama-tama harus mulai dari sikap dan keteladanan hidup yang baik. Setelah itu diikuti dengan dialog yang positif yang tidak merusak tatanan hidup yang rukun tersebut. 